\title{
STABILITAS STRUKTUR TANAH CANDI SUKUH: SAAT INI DAN MENDATANG
}

\section{SOIL STRUCTURE STABILITY OF THE SUKUH TEMPLE: PRESENT AND FUTURE}

\author{
Hendy Soesilo \\ Balai Arkeologi D.I. Yogyakarta \\ hendy.soesilo@kemdikbud.go.id
}

\begin{abstract}
The research of soil structure stability at Sukuh Temple was carried out in order to seek the answer to geotechnical and geological issues of the temple's environment. This National Heritage Site, which, was built around $14^{\text {th }}$ century AD, has some environment disturbances caused by developing settlement area, tourism, and mining. Furthermore, theexistence of mining activity at the site as shown by the tunnels and caves in the underground of the Temple's area, could makepotentiall triggers for landslide in the future of the temple.

Considering the major influence of mining activity in the area of this site, the soil structure study is necessery for focusing to assess the threats caused by this mining activity in the Temple's area. Geotechnical survey and geological survey condition have been done to collect data for this study. The survey were also been done for identifying other aspect such as earthquake in surrounding area of the Temple.
\end{abstract}

Keyword : Sukuh Temple, Development Area, Slope Stability.

\begin{abstract}
ABSTRAK
Penelitian stabilitas struktur tanah Candi Sukuh dilaksanakan untuk mengatasi permasalahan geoteknik dan geologi lingkungan candi. Pada saat ini kawasan Candi Sukuh yang merupakan situs lingkungan benda cagar budaya peninggalan abad ke 14, telah mengalami gangguan ekosistem karena adanya perkembangan wilayah pemukiman, wisata, serta berbagai kepentingan masyarakat lainnya seperti penambangan Gol C yang meninggalkan sisa galian berupa lorong dan gua di dalam tanah, yang dapat memicu pergerakan tanah berupa longsoran.

Oleh karena pertimbangan pelestarian maka dilaksanakan penelitian struktur tanah yang ada di kawasan Candi Sukuh, terutama mengenai kemungkinan akibat perubahan lingkungan dari kegiatan penambangan. Penelitian dilakukan dengan melaksanakan survey terhadap kondisi geoteknik, geologi, dan kemungkinan pengaruh lain misalnya gempa, terhadap kawasan candi.
\end{abstract}

Kata Kunci : Candi Sukuh, Perkembangan Wilayah, Kestabilan Lereng.

Tanggal masuk : 30 Juni 2015

Tanggal diterima : 04 Mei 2016 


\section{PENDAHULUAN}

Candi Sukuh terletak di lereng barat Gunung Lawu, pada ketinggian $1.186 \mathrm{~m}$ dari permukaan air laut dan koordinat $7^{0} 37^{\prime} 38^{\prime \prime}$ LS $111^{0} 7^{\prime} 52^{\prime \prime}$ BT. Secara administratif, candi ini terletak di dusun Sukuh desa Sumberejo, Kecamatan Ngargoyoso, Kabupaten Karanganyar, Jawa Tengah dengan jarak sekitar $20 \mathrm{~km}$ dari kota Karanganyar dan $36 \mathrm{~km}$ dari Kota Solo. Candi ini merupakan cagar budaya peninggalan Kerajaan Majapahit yang dibangun pada abad 14 Masehi.
Belanda. Pemugaran pertama dilakukan oleh Oudheidkundige Dienst in Nederlandsch-Indie (Jawatan Purbakala Hindia-Belanda) pada tahun 1917. Pada akhir tahun 1970 candi Sukuh mengalami pemugaran kembali oleh Departemen Pendidikan dan Kebudayaan( Lap. BSKB).

Saat ini kawasan sekitar Candi Sukuh telah mengalami perubahan lingkungan akibat adanya pengembangan pembangunan sektor pariwisata dan penambangan bahan tambang golongan $\mathrm{C}$ yang mengakibatkan lahan hutan semakin sempit. Candi Sukuh yang berdiri di

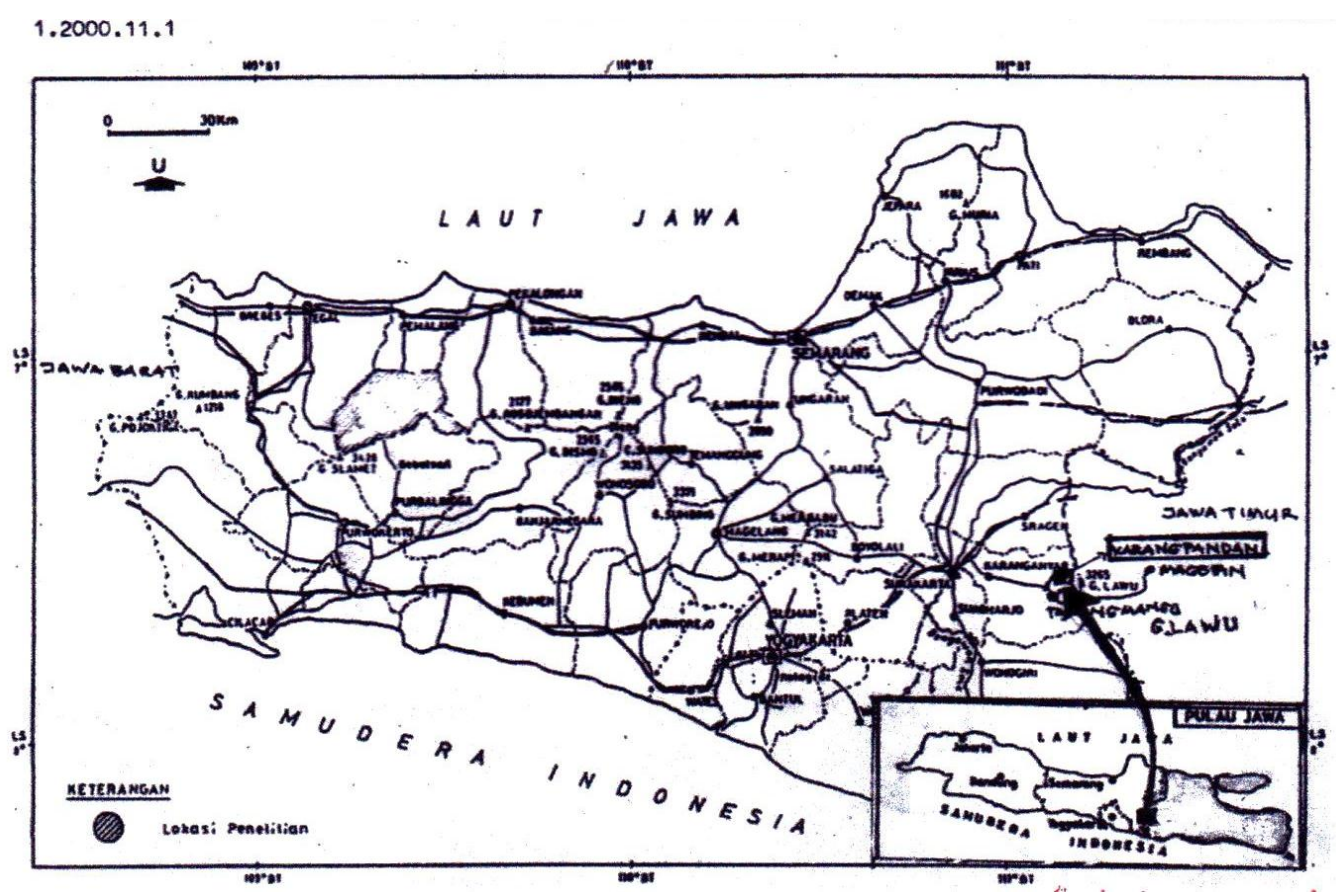

Gambar 1. Peta lokasi Penelitian Candi Sukuh

(Dok. BSKB Borobudur)

Candi Sukuh mempunyai arsitektur yang khas karena adanya penyimpangan bentuk bangunan Candi hindu pada umumnya. Situs yang dibangun pada akhir pengaruh Hindu di Jawa ini memiliki bentukbentuk teras berundak tinggi. Keunikan candi ini menyebabkan adanya upaya pelestarian Candi Sukuh telah dilakukan sejak zaman atas tanah residual hasil pelapukan mempunyai komposisi kandungan humus dan pasir lempungan yang dominan, yang terletak di atas batuan dasar satuan breksi andesit piroksen yang mulai rapuh. Kondisi kandungan tanah pelapukan inilah yang saat ini dimanfaatkan masyarakat sebagai bahan tambang golongan $\mathrm{C}$ berupa pasir dan batu. 
Matrial ini merupakanbidang batas kontak dari sisa-sisa gunung api kuno (volcanic neck) di Jawa dan bersifat impermeable yang dapat merupakan sebagai bidang gelincir. (bidang lapisan satuan yang massif dan mampu melongsorkan batuan lainnya). Pada saat ini kerusakan lingkungansekitar kawasan situs sudah pada tahapan kondisi rawan bencana, karena adanya penambangan galian Cyang dilakukan penduduk dengan berbagai alasan ekonomi.

Penambangan dilakukan dengan tambang terbuka (open pit) dari singkapan-singkapan yang tererosi yang kemudian dilanjutkan dengan aktivitas penambangan dengan mengejar jalur lewat batubatu pasir (breksi andesit piroksin) di dalam tanah dengan menggali lorong-lorong (tunnel) dari goa-goa yang ada di sekitar kawasan situs. Kegiatan penambangan ini membahayakan dan akan mengakibatkan penurunan daya dukung tanah di Kawasan situs, yang bilamana tidak diantisipasi dini dapat menyebabkan terjadinya bencana berupa longsoran dan gerakan tanah lainnya. Sehubungan adanya permasalahan tersebut, maka target pelaksanaan penelitian adalah untuk memperhitungkan kemungkinan penyebab paling utama dari faktor gerakan tanah, yaitu adanya gua-gua dan lorong bekas tambang galian pasir dan batu di kawasan situs.

Seluruh kegiatan yang dilakukan di sekitar Candi Sukuh haruslah memperhitungkan faktor internal dan eksternal dari lingkungan candi, antara lain adanya kemungkinan perubahan struktur tubuh tanah akibat perubahan iklim dan lingkungan serta adanya gangguan gempa vulkanik maupun tektonik. Kondisi tubuh tanah Candi
Sukuh pada saat ini mulai lapuk (termasuk batuan dasarnya). Maka perlu diantisipasi permasalahan daya dukung tanahnya untuk dapat diketahui kemungkinankemungkinan hal-hal yang akan timbul akibat adanya pengembangan aktifitas manusia. Perencanaan pemanfaatan yang tepatguna diharapkan dapat melestarikan benda cagar budaya yang ada.

Penelitian geoteknik: khususnya stabilitas lereng Candi Sukuh ini difokuskan pada penelitian terhadap sifat fisik dan daya dukung candi. Permasalahan daya dukung tanah kawasan Candi Sukuh yang diakibatkan oleh aktivitas penambangan golongan $\mathrm{C}$, baik berupa tinggalan gua dan lorong bawah tanah yang ada di sekitar kawasan candi tersebut menjadi pertimbangan utama dalam rangka penelitian kerawanan stabilitas lereng kawasan Candi Sukuh yang secara tidak langsung akan mempengaruhi struktur tanah pendukung situs yang ada, serta membahas aspek-aspek analisis pengembangan yang tepat guna sesuai dengan kaidah penataan geologi lingkungan dan arkeologi kawasan candi.

Lokasi daerah penelitian terletak pada jalur jalan raya Solo Tawangmangu lewat Karanganyar, Karangpandan. Sebagian besar daerah penelitian dapat dicapai oleh kendaraan roda empat dan sebagian dengan jalan kaki. Kondisi geografis bagian Utara merupakan lembah dan punggungan bukit, bagian Selatan merupakan punggungan bukit yang dapat dicapai dengan roda dua, sedang bagian Barat dan Timur merupakan lereng punggungan bukit Batu Jamus yang hanya dapat dicapai dengan jalan kaki. 
Metode penelitian lapangan dilaksanakan dengan menggunakan metode pemetaan geologi permukaan (surface geological mapping), pengamatan batuan, gejala geologi, pengukuran kemiringan lapisan tanah dan lereng, serta pencatatan dan pengambilan contoh batuan. Untuk permasalahan khusus (detail), dilakukan metode pengambilan sampel secara sistematis (sistematic sampling method), yaitu metode pengambilan contoh batuan secara sistematis dengan trance, serta dilakukan pemetaan stratigrafi dengan metode Measuring Section (MS).

\section{DATA DAN ANALISIS}

\section{A. Gambaran Umum Daerah Penelitian}

Daerah penelitian

terletak pada lereng sebelah Barat Gunung Lawu, Kabupaten Karanganyar, Propinsi Jawa Tengah, pada perbatasan morfologi tubuh gunung dan kaki gunung. Secara umum di bagian Utara daerah penelitian merupakan perbukitan bentang alam yang bergelombang sedang dan bagian Selatan terkena pengaruh struktur yang sangat kuat dapat berupa perbukitan terjal dan dataran bergelombang, dengan sebagian berupa kerucut terjal yang merupakan terobosan batuan beku.

Bentang alam di wilayah penelitian yang bergelombang, terbentuk dari aliran breksi lava dan jatuhan piroklastik, yang saat ini tingkat pelapukannya tinggi dengan tingkat erosi sedang. Tumbuhan yang ada berupa tanaman keras, perkebunan, palawija serta tanaman padi.
B. Dasar dan Teori Penelitian

Analisa stabilitas lereng didasarkan pada konsep keseimbangan batas plastisitas, yang dimaksudkan adalah untuk menentukan faktor aman dari bidang longsor yang potensial. Dalam analisis stabilitas lereng dapat dibuat beberapa anggapan yaitu:

- Kelongsoran lereng terjadi di sepanjang permukaan bidang longsor tertentu dan dapat dianggap sebagai masalah bidang 2 dimensi.

- Masa tanah yang longsor dianggap berupa benda yang masif.

- Tahanan geser dari masa tanah pada setiap titik sepanjang bidang longsor tidak tergantung dari orientasi permukaan longsoran, atau dengan kata lain kuat geser tanah dianggap isotropis.

Faktor aman adalah memperhatikan tegangan geser rata-rata sepanjang bidang longsor yang potensial dan kuat geser tanah rata-rata sepanjang permukaan longsoran. Jadi kuat geser tanah mungkin terlampaui pada titik-titik tertentu pada bidang longsornya, bilamana faktor aman (Save Factor) SF = 1. Faktor aman (SF) didefinisikan sebagai nilai banding antara gaya yang menahan dan gaya yang menggerakkan (Abramson dkk, 1996)

$$
F=\tau / \tau d
$$

Dimana $\mathrm{T}$ adalah tegangan geser yang dapat 
digerakkan oleh tanah dan Td adalah tegangan geser berat tanah yang akan yang terjadi akibat gaya

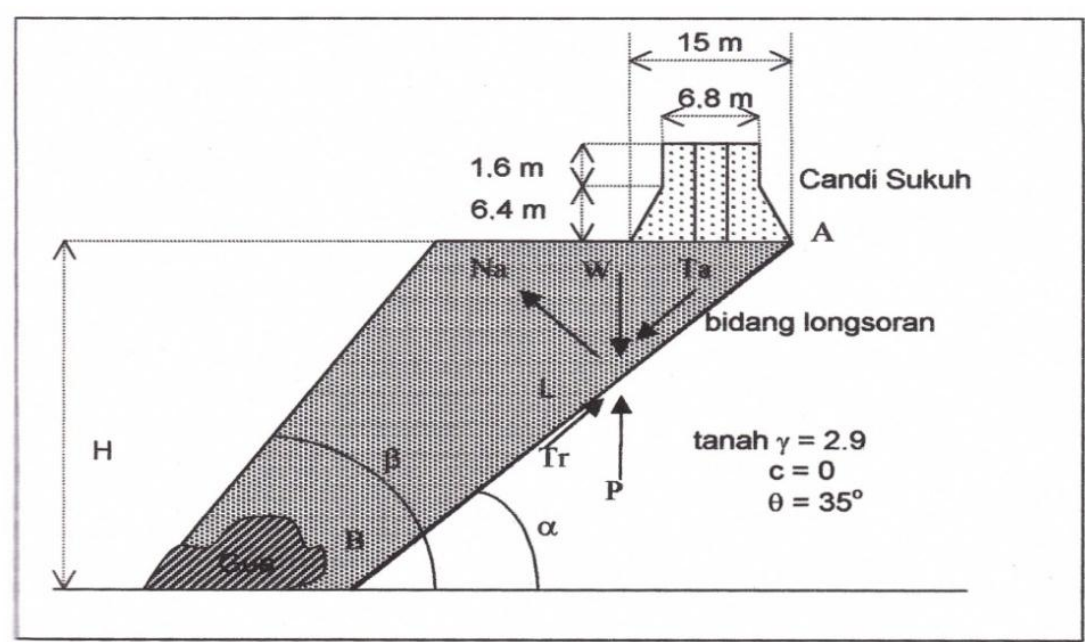

Keterangan :

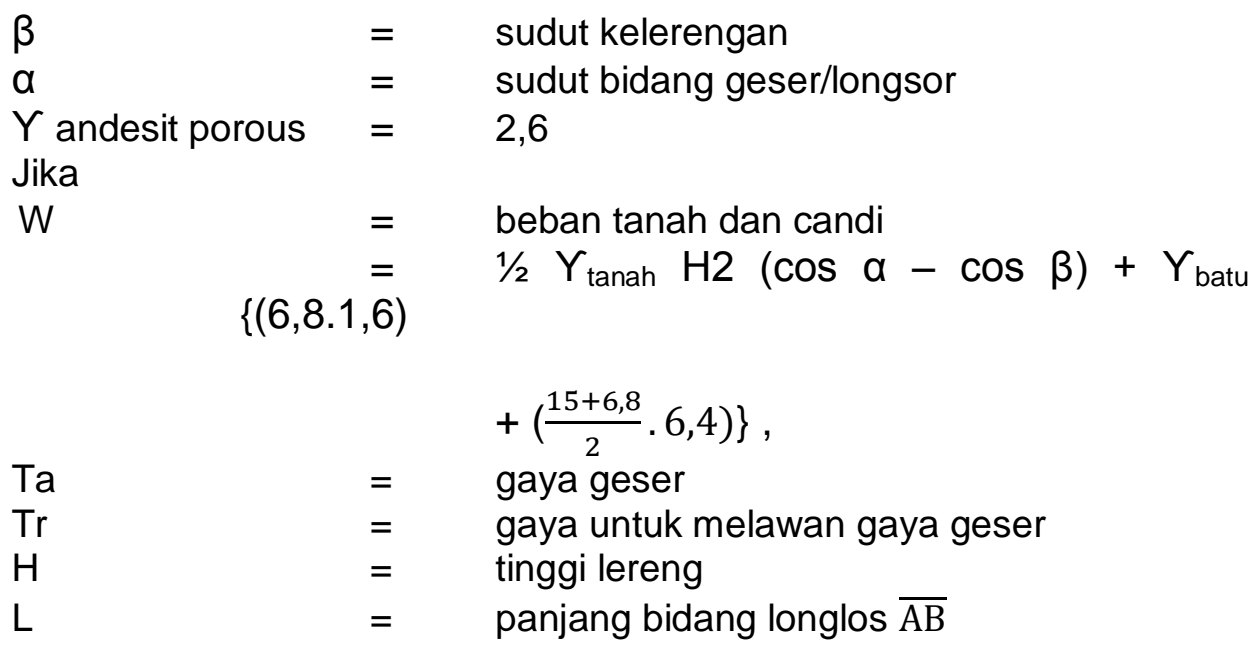

maka :

Gaya geser $\mathrm{Ta}=\mathrm{W} \sin \alpha$

Tahanan geser tanah yang dikerahkan untuk seimbang

$\operatorname{Tr}$

$$
\begin{array}{ll}
= & \mathrm{L}(\mathrm{Cd}+\sigma \operatorname{tg} \varnothing \mathrm{d}) \\
= & \mathrm{L}\left(\frac{\mathrm{c}}{\mathrm{F}}+\frac{\mathrm{Na}}{\mathrm{L}}+\frac{\operatorname{tg} \emptyset}{\mathrm{F}}\right) \\
= & 1 / \mathrm{F}(\mathrm{Lc}+\mathrm{Na} \operatorname{tg} \varnothing)
\end{array}
$$

Dimana :

$\mathrm{Na}$

$\mathrm{S}$

$=\quad W \cos \alpha$

c

$=\quad \overline{\mathrm{AB}}=\mathrm{H} \sin \alpha$

$=\quad$ kohesi tanah

$\varnothing \quad=\quad$ sudut gesek dalam dari tanah 
Pada kondisi seimbang $\mathrm{Ta}=\mathrm{Tr}$

(internal friction)

$1 / F(L c+W \cos \operatorname{tg} \varnothing) \quad=W \sin \alpha$, maka :

$$
\mathrm{F}=\frac{\mathrm{W} \cos \alpha \cdot \operatorname{tg} \emptyset+\mathrm{Lc}}{\mathrm{W} \sin \alpha}
$$

Pasir padat tidak berkohesi $(c=0)$ dan punya nilai $\varnothing=35^{\circ}$, maka persamaan menjadi sederhana:

$$
\mathrm{F}=\frac{\cos \alpha \cdot \operatorname{tg} 35^{0}}{\sin \alpha}=\frac{\cos \alpha \cdot 0,7}{\sin \alpha}
$$

Analisis kestabilan lereng seperti yang diuraikan tersebut di atas, belum memperhitungkan pengaruh gempa bumi. Apabila pengaruh gempa diperhitungkan maka metode keseimbangan batas dapat dimodifikasi dengan memasukkan pengaruh percepatan gempa untuk menghitung faktor aman.

Gaya gempa diasumsikan proporsional dengan berat tanah yang berpotensi longsor dikalikan dengan koefisien gempa (Abramson dkk, 1996)

Percepatan gempa desain, ad dapat dinyatakan dengan rumus :

$$
\mathrm{ad}=\mathrm{b}_{1}\{\text { ac. } \mathrm{z}\}^{\mathrm{b}_{2}}
$$

Dimana b1 dan b2 adalah koefisien tanah/batuan. Lokasi Candi Sukuh parameter b1 $=0,87$ dan b2 $=$ 1,05 (data parameter BGV).Parameter ac adalah percepatan gempa darat (gal).Parameter $z$ adalah koefisien zona bernilai 1 untuk lokasi solo, Jogja dan sekitarnya, dengan mempergunakan periode gempa ulang 100 tahun, nilai $\quad \mathrm{ac}=160$ gal $=160 \mathrm{~cm} /$ detik $^{2}$.
Koefisien gempa dirumuskan sebagai berikut :

$$
\mathrm{k}=\frac{\mathrm{ad}}{\mathrm{g}}
$$

Dimana $\mathrm{g}$ adalah percepatan gravitasi $=980 \mathrm{~cm} /$ detik $^{2}$.

Berdasarkan hal tersebut di atas nilai koefisien gempa, $\mathrm{k}$ untuk daerah Candi Sukuh adalah sebesar $\mathrm{k}=0,183$.

\section{Keadaan Geologi Daerah Penelitian}

1) Geomorfik Penelitian

Daerah Model yang tepat dan dapat dipergunakan untuk daerah penelitian yang merupakan daerah vulkanik adalah model menurut Van Zuidam (1983) yang membagi menjadi empat satuan geomorfik antara lain :

- Satuan geomorfik lereng kaki gunung api

- Satuan geomorfik perbukitan gawir sesar

- Satuan geomorfik depresi graben 
- Satuan geomorfik isolated hills

Berdasarkan model tersebut di atas, daerah penelitian adalah merupakan kombinasi satuan geomorfik lereng kaki gunung api dan geomorfik isolated hills.

Koefisien kelerengan :

$\mathrm{K}=$ tinggi vertikal / jarak horisontal $\mathrm{x}$ 100\% (Otto, 1991)

Rata-rata indeks kemiringan lereng daerah penelitian berkisar antara $10 \%$ sampai $30 \%$.

Pada sisi Utara dan Barat dengan klasifikasi lereng terjal mencapai $\mathrm{K}=30 \%$, sebelah Selatan Candi Sukuh $\mathrm{K}=10 \%$, sedang sebelah Timur yang berbatasan dengan daerah Perhutani dengan kemiringan lereng mencapai $\mathrm{K}=$ $12 \%$.

\section{2) Struktur Geologi Daerah Penelitian}

Berdasarkan geologi regional Candi Sukuh terbentuk karena pengaruh pergerakan lempeng Asia, Pasifik, serta Australia. Pengaruh pergerakan ini yang paling kuat adalah di pulau Jawa, yang menimbulkan aktivitas gunung api serta gaya kompresi yang secara umum terjadi dari arah Selatan ke Utara. Proses ini mengakibatkan terjadinya struktur perlipatan (merupakan suatu perbukitan yang memanjang), sesar antara lain berupa graben yang terdapat di sisi Utara dan Barat Candi Sukuh ditunjukkan oleh adanya lereng yang terjal, kemungkinan sebagai gawir sesar (faultscrap).

$$
\text { Karakter daerah }
$$

penelitian yang mempunyai

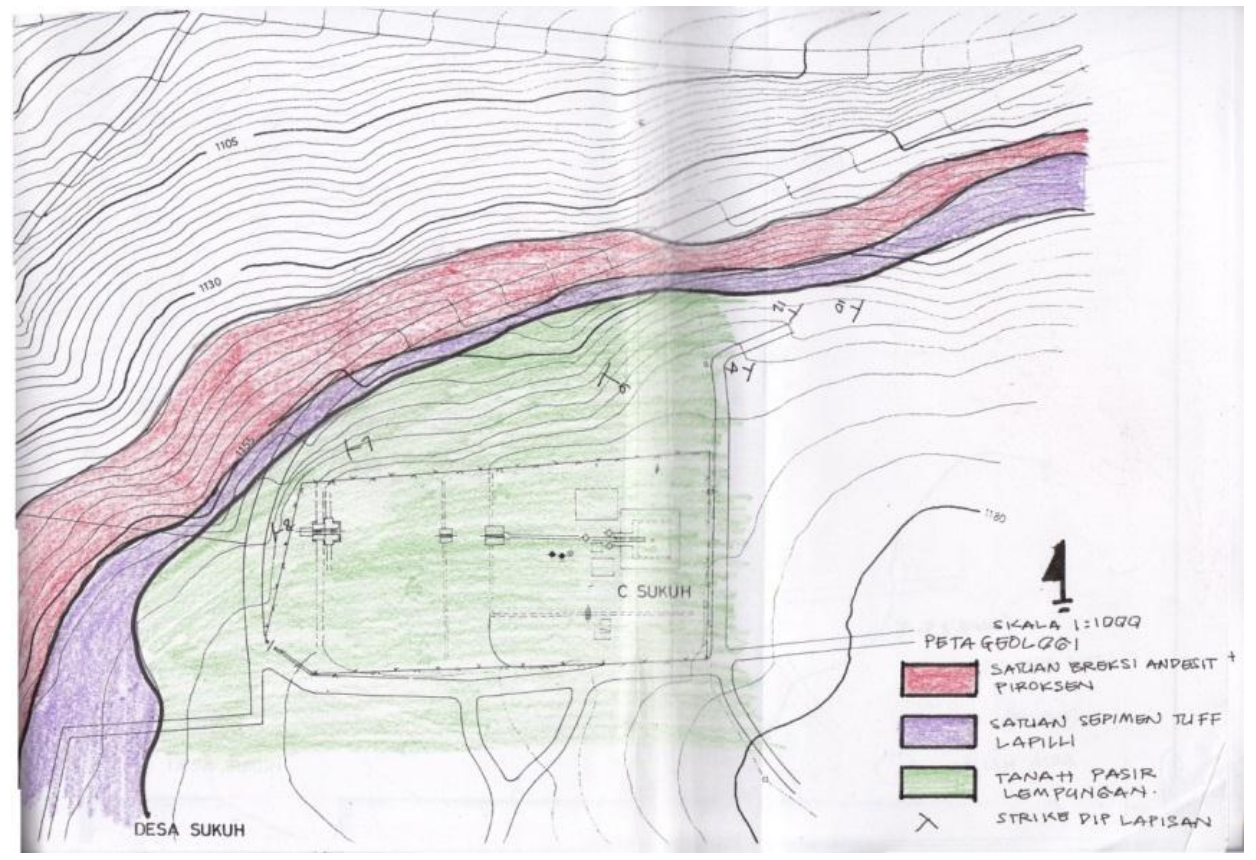

Gambar 2. Peta Geologi Kawasan Candi) Sukuh (dok. Penulis) 
kombinasi geomorfik seperti tersebut di atas mempunyai potensi bencana yang cukup besar. Oleh karena itu, ancaman-ancaman terhadap candi Sukuh haruslah diantisipasi agar bencana, misalnya tanah longsor dapat dihindari.

\section{3) Stratigrafi dan Litologi Daerah Penelitian}

Dari hasil pengamatan lapangan dan pengukuran secara measuring section di lapangan, satuan litostratigrafi dari yang berumur tua hingga ke muda adalah sebagai berikut:

Pada masa Plistosen atas (700.000 tahun yang lalu) diendapkan satuan breksi andesit piroksen yang tebalnya mencapai 125 meter yang merupakan tubuh batuan dasar dengan fragmen/ bongkah batuan dasar (basement) massif yang dapat bersifat impermeabel, namun saat ini batuan tersebut bagian atas/permukaannya telah mengalami pelapukan.

Batuan breksi andesit piroksen bersifat masif, sortasi jelek, kemas terbuka dengan terbentuknya retakan-retakan yang ada di dalam gua, bentuk fragmen sub angular, ukuran fragmen relatif seragam, diameter mencapai $25 \mathrm{~cm}$, berat jenisnya mencapai 2,6 , densitas $2,2 \mathrm{gr} / \mathrm{cm}^{3}$, porositasnya mencapai $17,6 \%$, dengan kuat tekan mencapai $500 \mathrm{~kg} / \mathrm{cm}^{2}$, komposisi andesit piroksen menunjukkan tekstur holokristalin porfiritik, komposisi mineral plagioklas (80\%), piroksen (10\%), mineral opak $(3 \%)$, yang tertanam pada massa dasar pasir vulkanik dan berlapis bersama lapili tuff, dimana singkapan batu pasir mempunyai sifat fisik berat jenis 2,51, densitasnya mencapai 2 $\mathrm{gr} / \mathrm{cm}^{3}$, porositasnya mencapai $19,8 \%$, dan kuat tekan mencapai $112,4 \quad \mathrm{~kg} / \mathrm{cm}^{2}$, sedangkan komposisi mineral fragmen breksi tuff dan lapili menunjukkan jenis sedimen piroklastik dengan komposisi mineral gelas mencapai $80 \%$, mineral lempung $10 \%$, oksida besi $3 \%$, homblende $2 \%$, piroksen $3 \%$, dan plagiokias $1 \%$, mineral opak $1 \%$ dengan nama batuan vitric tuff. Pada saat ini telah digali oleh penduduk setempat dengan membuat "caving" serta lorong "tunnel" di bawah permukaan tanah candi menjadi gua-gua.

Terdapat perlapisan pada tuff dengan gelas vulkanik memperlihatkan ciri dari wellded tuff yang terjadi karena proses

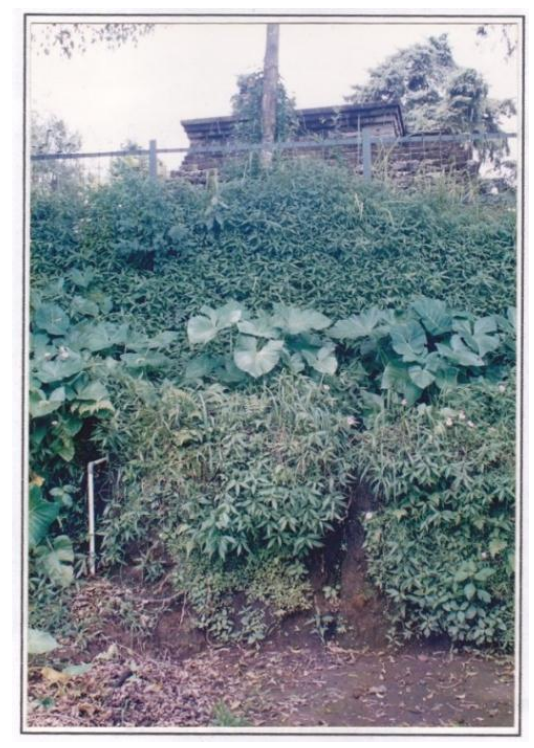

Gambar 3. Kenampakan perbedaan vegetasi yang tumbuh dan mencirikan perbedaan litologi yang ada pada sisi lereng utara (dok. Penulis). 
aliran piroklastik yang menumpuk secara cepat dengan tingkat suhu yang tak jauh berbeda / dan mendingin secara bersamaan dengan aliran lava hasil kegiatan gunung api yang bersifat effusif.

$\mathrm{Di}$ atas batuan tersebut pada masa resen (hingga saat ini) diendapkan material rombakan hasil vulkanisme yang terdiri dari batuan tuff lapili dan berlapis berwarna abu-abu kecoklatan, lapuk berwarna coklat, ketebalan mencapai 75 $\mathrm{cm}$. Kemudian di atas batuan tuff lapili terdapat lapisan tanah hasil pelapukan berupa humus, pasir lempungan yang berwarna kekuningan dan relatif abu-abu, ketebalan mencapai 2 meter. Spesifikasi teknis dari kondisi tanah yang ada di sekitar Candi Sukuh, densitas 2,5 - 2,9 gr/ $\mathrm{cm}^{3}$, BJ 2,08, kadar air 92,3\%, porositas mencapai 7,4\% dengan $\mathrm{pH}=5$.

\section{Analisis Geoteknis Daerah Penelitian}

Pada daerah penelitian sisi Utara (zona penyangga/

Tabel 1. Kolom Stratigrafi Daerah Penelitian

\begin{tabular}{|c|c|c|c|l|}
\hline Umur & Tebal & Litologi & \multicolumn{1}{c|}{ Struktur } & \multicolumn{1}{c|}{ Keterangan } \\
\hline Resen & 2 meter & & Tanah pasir lempungan \\
\hline $\begin{array}{l}\text { Plistosen } \\
\text { atas }\end{array}$ & 125 meter & $\begin{array}{c}\text { tidak } \\
\text { selaras }\end{array}$ & abu-abu dan kekuningan \\
\hline & & $\begin{array}{c}\text { tidak } \\
\text { selaras }\end{array}$ & tuff lapili \\
\hline
\end{tabular}

bufferzone).

Dengan kemiringan lereng yang terjal, mencapai $30 \%$ serta kondisi tanah pasir lempungan yang kohesinya tidak terlalu lekat serta merupakan komponen terurai (unconsolidated detritus), material lepas yang bersifat permeabel (1 $\mathrm{cm} / \mathrm{dt})$ yang mudah meluluskan air, maka daerah ini mudah sekali untuk terjadi longsoran, sebab terletak di atas batuan dasar andesit piroksen yang lebih impermeabel dan dapat sebagai pemicu bidang gelincir.

Pada sisi Utara terdapat gua-gua hasil tambang oleh penduduk untuk diambil sebagai batu lepas/tras dan pasir dari tuff lapili yang telah lapuk, penambangan ini untuk sementara telah dihentikan, karena kondisi tingkat kerawanan struktur tubuh tanah Candi Sukuh.

Catatan : tanpa skala 


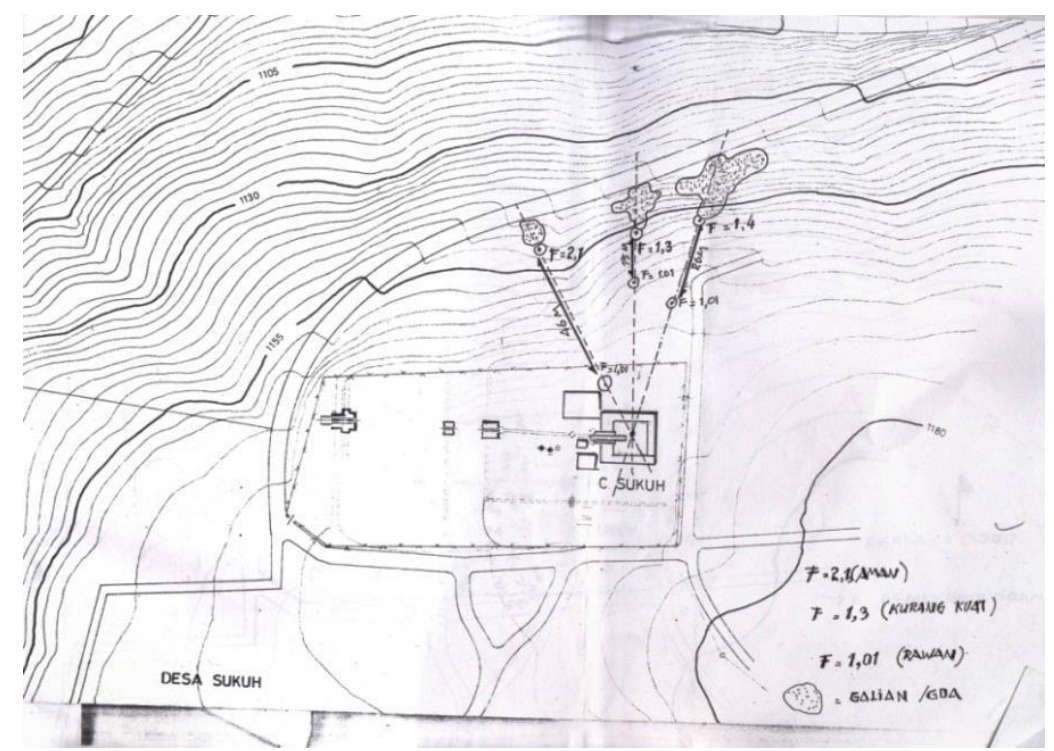

Gambar 4. Peta Keletakan Lokasi Gua pada Kawasan Candi Sukuh (dok. Penulis)

Dengan mempergunakan perhitungan secara grafis dan data lokasi dapat dihitung angka aman dari masing-masing gua adalah sebagai berikut :

\section{1). Geoteknik Gua I}

Analisis Perhitungan

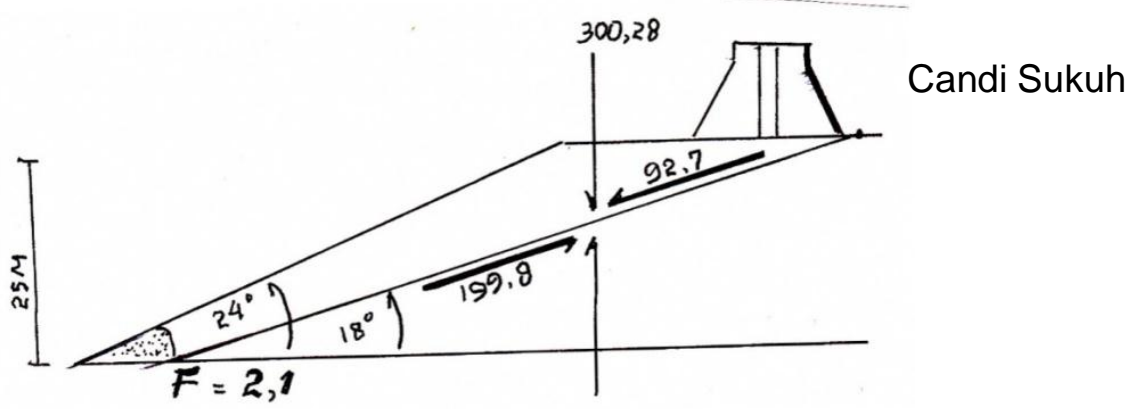

$$
\begin{array}{ll}
\mathrm{W}=1 / 2 \cdot 2,9 \cdot 25^{2}(0,806-0,766)+209,66 & =300,28 \text { ton } \\
\text { Gaya geser } & =199,899 \text { ton } \\
\text { gaya penahan } & =92,788 \text { ton } \\
\text { sudut lereng }(\beta) & =24^{0} \\
\text { sudut bidang geser }(\alpha) & =18^{0}
\end{array}
$$

$$
\mathrm{F}=\frac{\cos 18^{0} \operatorname{tg} 35^{0}}{\sin 18^{0}}=\frac{0,9510.0,7}{0,3090}=2,1(\mathrm{aman})
$$

Dengan memperhitungkan kemungkinan pengaruh gempa, maka analisis perhitungan adalah sebagai berikut : 


$$
\begin{aligned}
& F=\frac{\left(\cos 18^{0}-\mathrm{k}\right) \times \operatorname{tg} 35^{0}}{\left(\sin 18^{0}+\mathrm{k}\right)} \\
& =\frac{(0,951-0,183) \times 0,7}{(0,309+0,183)} \\
& =\frac{0,5379}{0,4920} \\
& =1,09 \text { (aman limit) }
\end{aligned}
$$

$\begin{array}{ll}\text { Gaya geser } & =147,74 \text { ton } \\ \text { Gaya penahan } & =161,43 \text { ton }\end{array}$

- Analisis Pengurugan

Kedalaman gua nomor I adalah lebih kurang 8 meter, tinggi lebih kurang 2 meter, lebar lebih kurang 4 meter, bentuk oval terpancung. Prediksi volume $= \pm(8 \times 4 \times 2) \mathrm{m}^{3}=32 \mathrm{~m}^{3}$

Koefisien jumlah volume penyusutan untuk pengurangan sirtu sebanyak 1,3 . Untuk keamanan diperlukan bahan urugan tanah, pasir dan batu sebanyak: $1,3 \times 32 \mathrm{~m}^{3}=42 \mathrm{~m}^{3}$

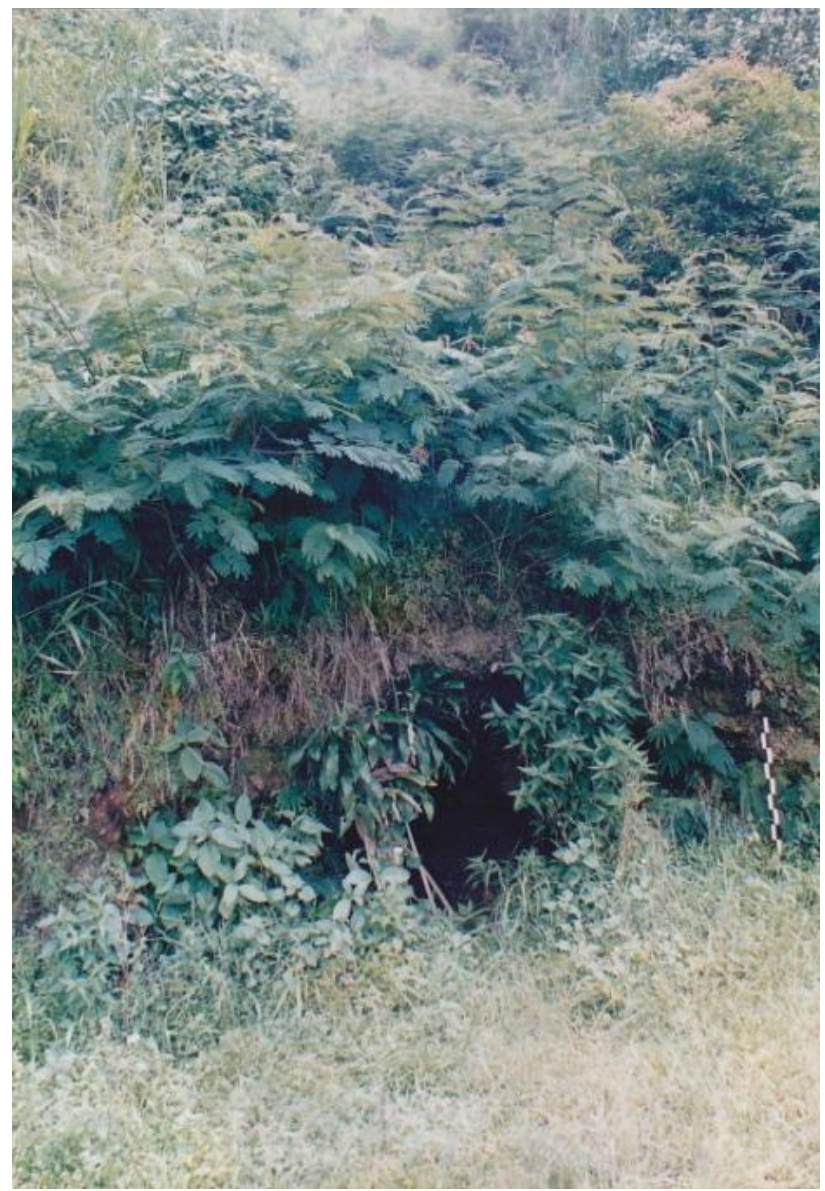

Gambar 5. Lorong pintu Gua I yang sempit, terletak di bawah lereng sisi Utara dan mempunyai SF 2,1 (aman) (Dok. Penulis) 


\section{2). Geoteknik Gua II}

- Analisis Perhitungan

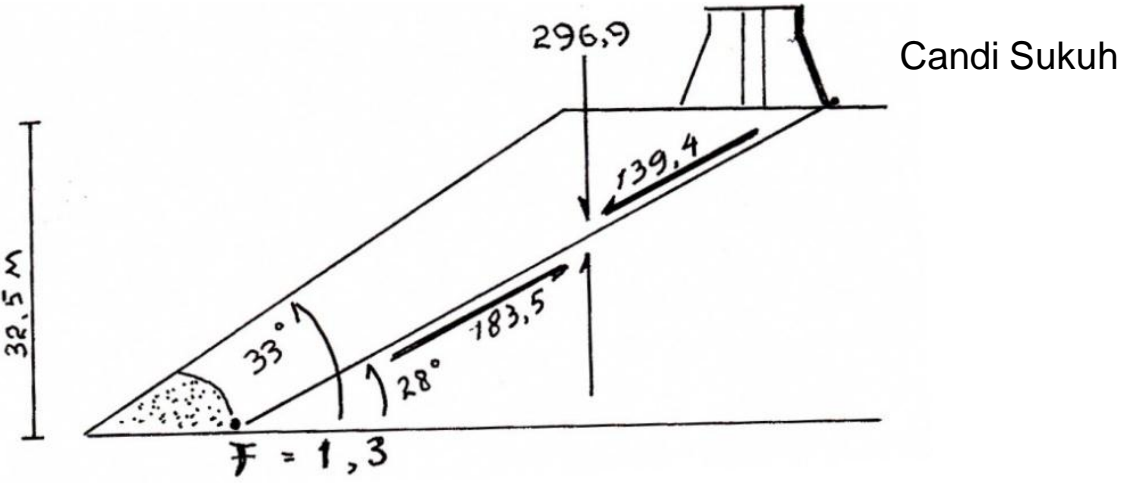

$W=1 / 2 \cdot 2,9 \cdot 32,52(0,707-0,643)+209,66=296,9$ ton

gaya geser

gaya penahan

sudut lereng

sudut bidang geser

$\begin{array}{ll}= & 139,4 \text { ton } \\ = & 183,5 \text { ton } \\ = & 33^{0} \\ = & 28^{0}\end{array}$

$=28^{0}$

$$
\mathrm{F}=\frac{\cos 28^{0} \operatorname{tg} 35^{\circ}}{\sin 28^{0}}=1,3(\mathrm{aman})
$$

Bilamana pengaruh gempa bumi diperhitungkan :

$$
\begin{aligned}
F & =\frac{\left(\cos 28^{0}-\mathrm{k}\right) \times \operatorname{tg} 35^{0}}{\left(\sin 28^{0}+\mathrm{k}\right)} \\
& =\frac{(0,883-0,183) \times 0,7}{(0,469+0,183)} \\
& =\frac{0,49}{0,652} \\
=0,7 & \text { (resiko longsor) }
\end{aligned}
$$

Gaya geser $\quad=193,58$ ton

Gaya penahan $=145,48$ ton

- Analisis Pengurugan

Kedalaman gua nomor II adalah lebih kurang 15 meter, tinggi lebih kurang 2,5 meter, lebar lebih kurang 15 meter, bentuk gua bercabang.

Prediksi volume $=+(15 \times 15 \times 2,5 \times 0,4) \mathrm{m}^{3}=250 \mathrm{~m}^{3}$

Untuk kestabilan tanah, maka diperlukan bahan urugan tanah, pasir dan batu sebanyak $250 \mathrm{~m} 3$. 


\section{3). Geoteknik Gua III}

Analisis Perhitungan

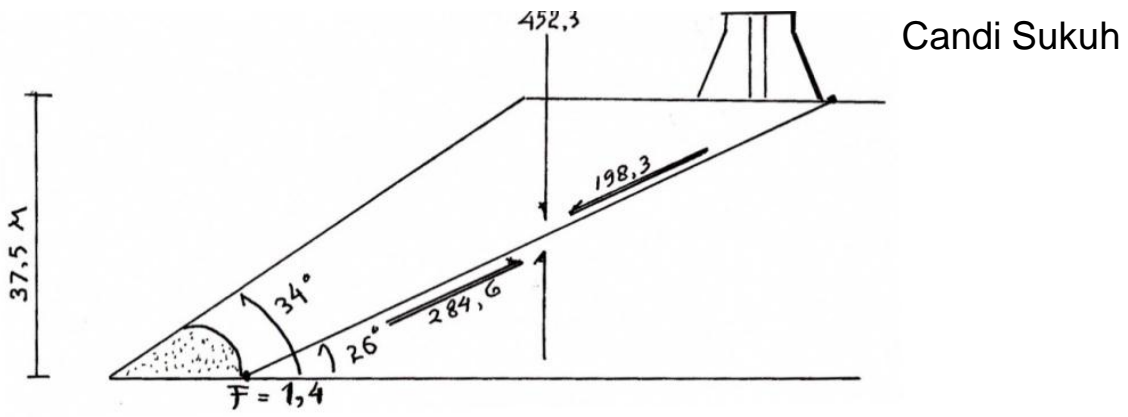

$\begin{array}{lll}\mathrm{W}=1 / 2 \cdot 2,9 \cdot 37,52(0,788-0,669)+209,66 & =452,3 \text { ton } \\ \text { gaya geser } & = & 198,3 \text { ton } \\ \text { gaya penahan } & = & 284,6 \text { ton } \\ \text { sudut lereng } & = & 34^{0} \\ \text { sudut bidang geser } & = & 26^{0}\end{array}$

$$
\mathrm{F}=\frac{\cos 26^{\circ} \operatorname{tg} 35^{0}}{\sin 26^{0}}=1,4(\mathrm{aman})
$$

Dengan memperhitungkan pengaruh gempa maka analisis menjadi :

$$
\begin{aligned}
& F=\frac{\left(\cos 26^{0}-\mathrm{k}\right) \times \operatorname{tg} 35^{0}}{\left(\sin 26^{0}+\mathrm{k}\right)} \\
&=\frac{(0,899-0,183) \times 0,7}{(0,438+0,183)} \\
&=\frac{0,501}{0,621} \\
&=0,8 \text { (resiko longsor) }
\end{aligned}
$$

Gaya geser $\quad=280,88$ ton

Gaya penahan $=226,60$ ton

Analisis pengurugan:

Kedalaman gua nomor III adalah lebih kurang 18 meter, tinggi lebih kurang 3 meter, lebar lebih kurang 17 meter, bentuk oval terpancung.

$\begin{aligned} & \text { Prediksi volume } \\ & \pm(18 \times 17 \times 3 \times 0,4) \mathrm{m}^{3}=368 \mathrm{~m}^{3}\end{aligned}=$

Diperlukan bahan urugan tanah, pasir dan batu sebanyak $368 \mathrm{~m}^{3}$
Dari ketiga gua tersebut analisis total tanah pasir batu yang diperlukan untuk pengurugan 3 gua adalah sebanyak $660 \mathrm{~m}^{3}$ atau sejumlah 165 truk.

Permasalahan lereng Candi Sukuh yang terdiri dari batu besar berupa breksi andesit piroksen serta tuff lapili yang sudah lapuk, kerakal dan pasiran yang menguatkan struktur tubuh tanah, mempunyai permeabilitas tinggi 
(1 cm/detik) dan sedikit lempung, struktur yang demikian merupakan tanah dengan daya dukung kecil.

Melihat hasil perhitungan analisis kestabilan lereng dan gua yang ada di Candi Sukuh, baik yang dipengaruhi gempa maupun tidak, maka dapat diklasifikasikan interpretasi sebagai berikut:

TABEL 2. STABILITAS TANAH \& GUA DI SEKITAR CANDI SUKUH

\begin{tabular}{|c|c|c|c|c|}
\hline \multirow{2}{*}{ GUA } & \multirow{2}{*}{ Sudut bidang geser $(\alpha)$} & \multicolumn{2}{|c|}{ SF } & \multirow{2}{*}{ Interpertasi } \\
\hline & & TG & DG & \\
\hline I & $18^{\circ}$ & 2,1 & 1,09 & $\begin{array}{c}\text { Aman, limit batas bila } \\
\text { ada gempa }\end{array}$ \\
\hline II & $28^{\circ}$ & 1,3 & 0,7 & $\underset{\text { terjadi }}{\text { Longsor bila gempa }}$ \\
\hline III & $26^{\circ}$ & 1,4 & 0,8 & $\begin{array}{l}\text { Dapat longsor bila } \\
\text { terjadi gempa }\end{array}$ \\
\hline
\end{tabular}

Keterangan:

$\mathrm{TG}=$ perhitungan tanpa gempa

$D G=$ perhitungan dengan gempa

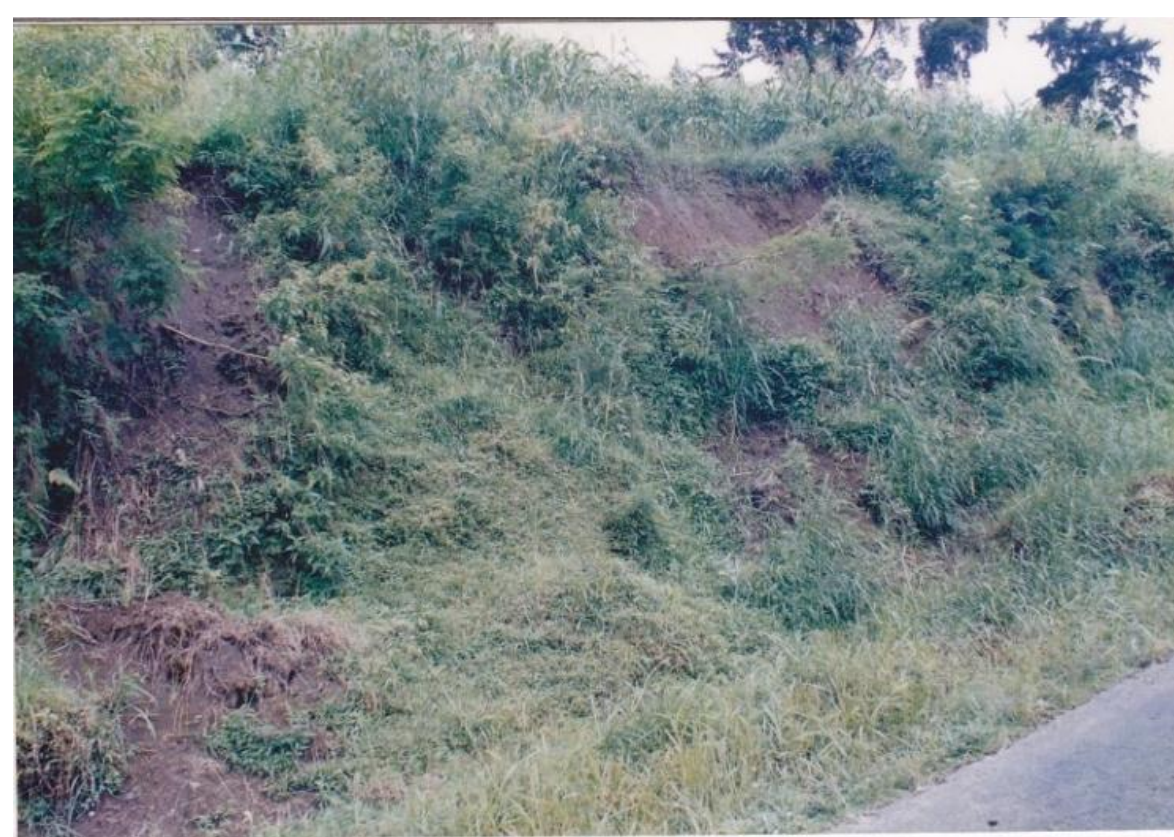

Gambar 6. Kenampakan lereng Utara yang mengalami longsoran kecil, karena kondisi tanah yang labil (Dok. Penulis) 
Hal yang mengkhawatirkan yaitu bila gua tidak diurug, maka air yang menetes dari langit-langit gua pasti membawa partikel tanah dari atap gua, hal ini akan mengurangi kekuatan struktur tubuh tanah.

Pada permukaan gua yang mempunyai lereng terjal, saat ini merupakan lahan pertanian, dimana tanah tersebut diolah dan dapat membuat tanah semakin gembur, sehingga menyebabkan tingkat erosi bertambah, pada kondisi lereng yang terjal akan semakin rawan terhadap kelongsoran.Gua yang ada pada saat ini, dari segi geoarkeologis dan geoteknis tidak memungkinkan untuk dibiarkan seperti apa adanya dan harus segera dilakukan penyelamatan dengan penimbunan.

\section{E. Geologi Tata Lingkungan \\ Dalam geologi tata} lingkungan bahwa sifat fisik merupakan suatu sebab yang akan memberikan suatu akibat dalam bentuk usaha pencegahan dan penanggulangan supaya dapat mencapai target untuk mendapatkan dampak positif semaksimal mungkin, serta dampak negatif seminimal mungkin sehingga kelangsungan kehidupan kelestarian alam dapat terjaga dan berjalan selaras.

Gunung api merupakan bagian suatu bahaya lingkungan maupun sumber alam yang tidak terpisahkan dari kehidupan manusia dan merupakan bagian dari suatu ekosistem. Dibawah ini akan dibahas tentang sumber alam di daerah penelitian seperti pertanian dan kehutanan bahan galian (C), air tanah dan air permukaan serta obyek pariwisata dari sudut pandang geologi.

\section{1). Pertanian dan Kehutanan.}

Pada daerah penelitian, lahan pertanian hanya dianjurkan pada sudut kelerengan di bawah

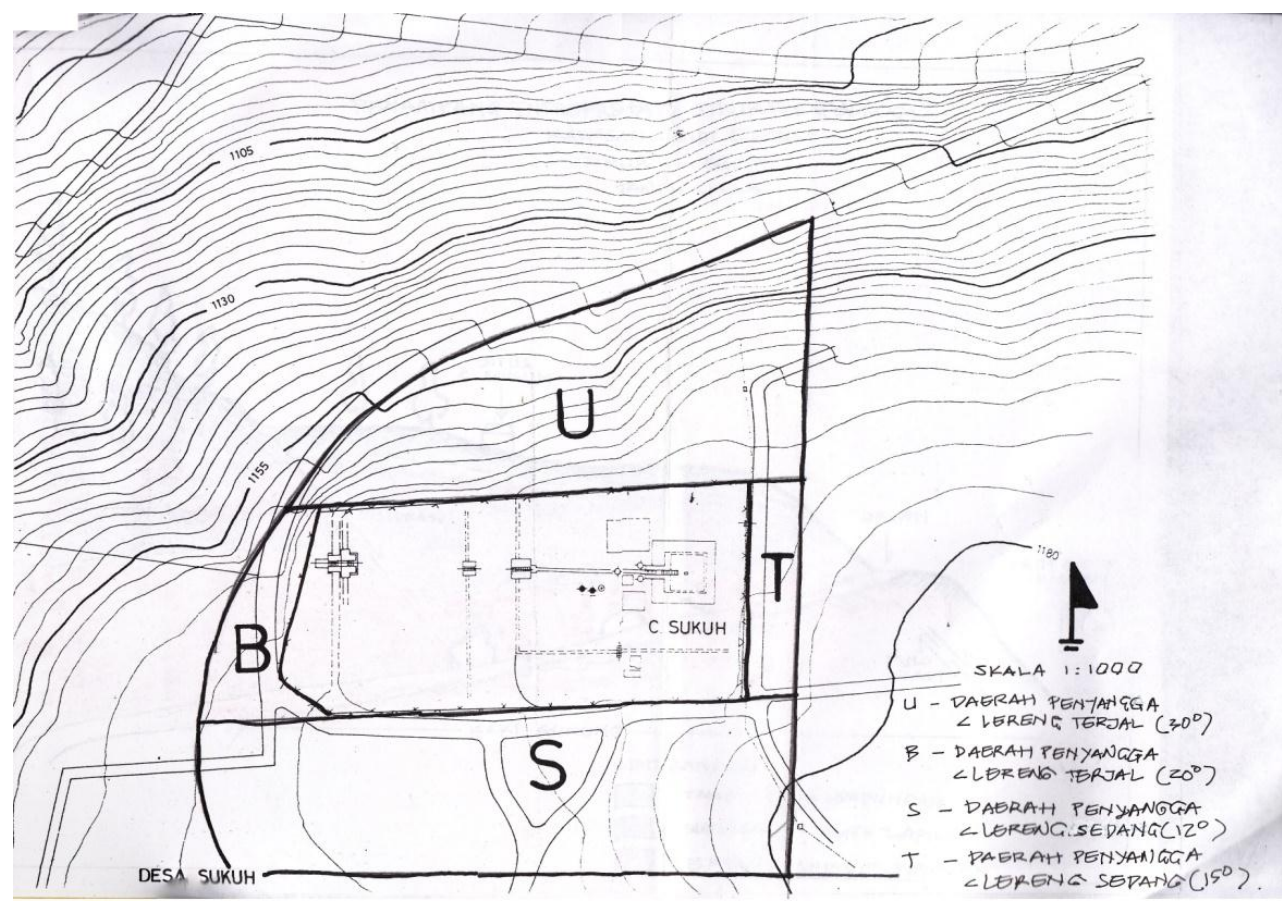

Gambar 7. Peta Geologi Tata Lingkungan Kawasan Candi Sukuh (dok.Penulis) 
$5 \%$ dan biasanya didekat pemukiman penduduk, sedang di sekitar Candi Sukuh yang mempunyai kelerengan dengan klasifikasi terjal (30\%) tidak dianjurkan untuk lahan pertanian, dikarenakan kondisi tubuh tanah mudah meluluskan air (permeabel), sehingga bila terletak di atas satuan tubuh tanah yang impermeabel (breksi andesit piroksen) dapat menyebabkan terjadinya longsoran.

Tanah hasil vulkanisme, sangat baik dan subur untuk tumbuhan bila unsur-unsur yang diperlukan lengkap, baik bersifat asam maupun basa. Biasanya tanah ini dihasilkan oleh batuan dasar yang bersifat intermediate dan akan menghasilkan $\mathrm{pH}$ netral.

Unsur lain yang tak kalah penting adalah air, daerah penelitian mempunyai curah hujan yang tinggi, rata-rata curah hujan pada daerah gunung api di Indonesia antara $3.000 \mathrm{~mm}$ sampai $6.000 \mathrm{~mm}$ per tahun.

Daerah perbukitan di sebelah Timur Candi Sukuh, mempunyai kondisi tanah dengan kemungkinan resiko erosi tinggi, namun demikian saat ini kawasan tersebut dalam penguasaan Departemen Kehutanan, akan lebih baik kondisinya tetap dipertahankan sebagai kawasan hutan lindung. Daerah kehutanan telah melaksanakan konservasi lahan secara baik berdasarkan kondisi tanah dan kepentingannya.

Kepentingan lahan hutan, adalah untuk daerah resapan air dan daerah penyangga (buffer zone)bagi daerah sekitar Candi Sukuh yang terletak pada lereng di bawahnya.

\section{2). Lingkungan IImiah}

Kawasan Candi Sukuh adalah merupakan situs benda cagar budaya yang penting untuk pengembangan studi sejarah kebudayaan manusia dan pengetahuan yang lainnya. Daerah ini dengan kondisi lingkungan serta ekosistem yang ada haruslah tetap dipertahankan seperti aslinya sehingga warisan budaya dan lingkungan tidak berubah karena kondisi jaman.

\section{3). Bahan Galian (C)}

Bahan galian yang ditambang berupa pasir vulkanik sebagai matrik dari breksi. Bongkah batuan beku ditemukan dalam jumlah yang banyak terutama sepanjang sungai dan banyak tersingkap di pinggir jalan. Bahan galian pasir vulkanik, berkaitan erat dengan pengendapan tuff, dapat dipergunakan sebagai tras untuk

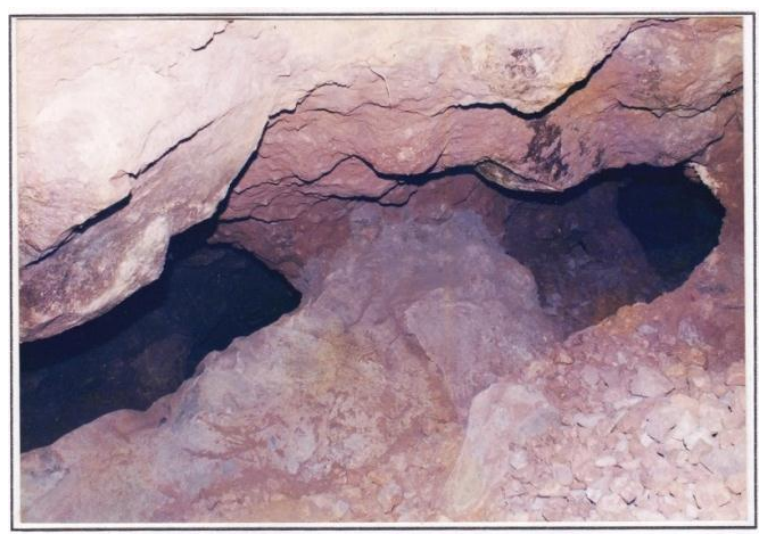

Gambar 8. Lorong Gua III berupa tunnel, yang digali mengikuti arah retakan dan bahan yang ditambang baik berupa pasir hasil pelapukan Tuff lapili dan batu hasil rombakan breksi andesit piroksen. (Dok. Penulis)

pencampur semen, namun kondisi mutunya rendah. 


\section{4). Air tanah dan Air Permukaan}

Air permukaan secara umum jernih, tak berwarna, tak berbau dan rasanya tawar dengan debit pengaliran yang besar, sehingga dari segi kualitas dan kuantitasnya baik.

Kondisi air limpasan permukaan dengan mempertimbangkan kondisi struktur tubuh tanah serta kelerengan yang ada jarang terjadi limpasan yang deras, secara umum di sekitar lingkungan dan halaman Candi Sukuh, arah limpasan dominan menuju ke arah Utara dan Barat. Oleh karenanya perlu untuk dibuat sistem peresapan dan sistem drainase terbuka dan tertutup yang baik di tempat yang diperkirakan tersebut di atas.

Air bawah tanah di sekitar Candi Sukuh dapat terjadi karena adanya zone retakan pada tubuh batuan breksi andesit piroksen yang terakumulasi dan terturap sebagai air tanah yang terkadang bersifat asam.

\section{5). Obyek Pariwisata dan Budaya}

Daerah penelitian yang mempunyai ketinggian mencapai 1.000 meter di atas permukaan air laut, dengan udara yang sejuk serta terletak pada celah graben suatu pegunungan, bagus untuk pengembangan daerah peristirahatan yang dapat dikombinasi sebagai lingkungan budaya.

\section{6). Bencana Alam}

Untuk daerah penelitian, bencana alam yang biasa terjadi dan mempunyai potensi tinggi berupa longsoran adalah karena kondisi tanah yang tidak stabil dan merupakan zona lemah yang

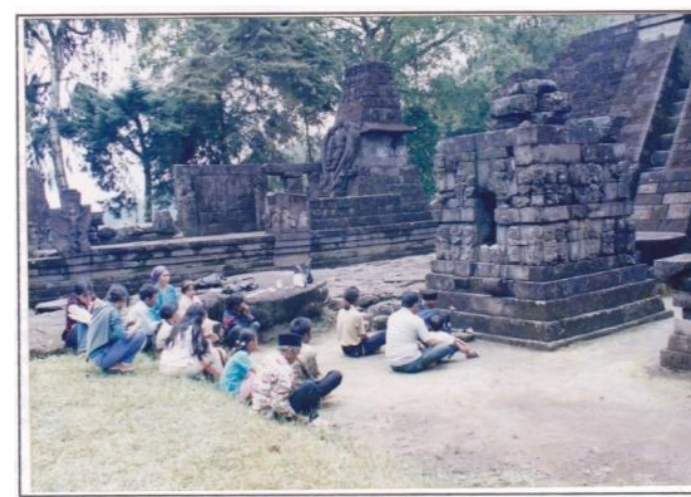

Gambar 9.Kegiatan ritual sebagai sumber budaya, pariwisata dan ilmu pengetahuan

(Dok. Penulis)

mempunyai lereng yang terjal. Hal ini dapat terjadi bilamana kondisi lingkungan berubah, karena kerusakan lahan akibat pemanfaatan yang tidak tepat seperti adanya penambangan golongan $\mathrm{C}$ dan kemungkinan potensi terjadinya gerakan tanah akibat gempa vulkanik maupun tektonik.

\section{KESIMPULAN DAN SARAN}

\section{A. Kesimpulan}

1. Kawasan Candi Sukuh terdiri dari batuan dasar breksi andesit piroksen yang berumur Plestosen Atas (700.000 tahun yang lalu). Lapisan tersebut mempunyai ketebalan lebih kurang 125 meter dengan kondisi yang sudah rapuh dan merupakan penyangga tubuh tanah yang terdiri dari pasir lempungan, berwarna abu-abu dan kekuningan. Mempunyai permeabilitas tinggi (1 $\mathrm{cm} /$ detik) yang cepat meresapkan air, serta rawan longsor.

2. Berdasarkan kondisi kelerengan serta struktur tubuh tanah pendukung 
Candi Sukuh, dapat diperhitungkan kestabilan tanah dan batu pada gua I sebesar $\mathrm{SF}=2,1$ (aman), dengan perhitungan pengaruh gempa SF menjadi 1,09 (klasifikasi aman, limit longsor bila terjadi gempa). Gua II SF = 1,3 (aman), dengan perhitungan pengaruh gempa SF menjadi 0,7 (klasifikasi longsor bila terjadi gempa). Gua III SF = 1,4 (aman), dengan perhitungan pengaruh gempa SF menjadi 0,8 (klasifikasi longsor bila terjadi gempa). Namun demikian kemungkinan pengaruh adanya rembesan air yang melalui rekahan batu akan membawa material tanah serta mengikisnya, dapat memicu terjadinya longsoran.

3. Melihat kondisi geografis dan geologis kawasan Candi Sukuh hanya dapat dikembangkan sebagai daerah tujuan wisata berwawasan kebudayaan, namun tidak untuk pengembangan daerah penambangan maupun lahan pertanian.

\section{B. Saran}

Berdasarkan keseimbangan akan ekosistem yang ada, hendaknya pemeliharaan dan pengelolaan lahan kawasan dilakukan secara menyeluruh dan berkesinambungan, sehingga kebijakan pencegahan dapat dilakukan sedini mungkin dan tidak dianjurkan untuk meneruskan penambangan golongan $\mathrm{C}$. Untuk pengurugan dan penutupan gua, apabila diperlukan dapat dilakukan dengan metode "close and fill". Perlu dilakukan

pembagian daerah penyangga (buffer zone), pada sisi Utara hanya dimanfaatkan untuk lahan tanam yang tidak memerlukan pengolahan tanah, dalam tata tanam hendaknya diperoleh perbandingan yang seimbang antara pemukiman, hutan dan tanah pertanian/perkebunan, misalnya dapat ditanami tanaman keras berupa buahbuahan, tanaman pelindung, dan lain sebagainya. Kondisi lereng sebelah Barat hendaknya tetap dipelihara seperti kondisi saat ini, sedang bagian Selatan tidak menambah bangunan permanen yang dapat menyebabkan daerah resapan air berkurang, sebelah Timur yang merupakan milik instansi Kehutanan bagus untuk potensi kawasan ekowisata (camping ground).

Sistem drainase dibuat
untuk peresapan air dan
pengaliran dengan baik,
sehingga air permukaan dapat
terkontrol, khususnya untuk sisi
Utara dan Barat.

\section{UCAPAN TERIMA KASIH}

Terima kasih disampaikan kepada Bapak Prof. Dr. Ir. Kabul Basah Suryolelono, Dip H.E, D.E.A Guru Besar Fakultas Teknik Sipil UGM sebagai KonsultanTim Geoteknis Penanganan Kestabilan Lereng Candi Sukuh - Jateng. 


\section{DAFTAR PUSTAKA}

Abramson L.W, Lee, T.S, Sharma S dan Boyce, G.M.. 1996, Slope Stability and Stabilitation Methods - John Wiley and sons. New York.

Amat Suwito. 1989. "Geologi Daerah Karangpandan, Kabupaten Karanganyar, Jateng”, Skripsi FT. Geologi UGM, Yogyakarta.

Cliff Ollier, Ollier \& Boyd Edinburg. 1991. Weathering - University of Papua and New Guinnea.

Ersin Seyhan. 1977, "Dasar-Dasar Hidrologi", Gajah Mada University Press, Yogyakarta.

Hary Christadi Hardiyatmo. 1994. Mekanik Tanah 2 - Gramedia Pustaka Utama Jakarta.

Hendy Soesilo dkk, (2000), "Studi Lingkungan Situs Tentang Rembesan Tubuh Tanah di Bawah Bangunan Candi Borobudur", Laporan Kerja Balai Studi dan Konservasi Borobudur.

Kabul Basah Suryolelono, Nafiri. 1999. Geosintetik - teknik - Yogyakarta

Otto Soemarwoto. 1991. "Analisis Dampak Lingkungan”, Gajah Mada University Press, Yogyakarta. 
